\title{
Morphometric and microsatellite-based comparative genetic diversity analysis in Bubalus bubalis from North India
}

\author{
Vikas Vohra ${ }^{\text {Corresp., }}{ }^{\text {, Narendra P Singh }}{ }^{1}$, Supriya Chhotaray ${ }^{1}$, Varinder S Raina ${ }^{2}$, Alka Chopra ${ }^{3}$, Ranjit S Kataria ${ }^{4}$ \\ ${ }^{1}$ Animal Genetics and Breeding Division, National Dairy Research Institute, Karnal, Haryana, India \\ 2 Department of Animal Husbandry and Dairying, Ministry of Fisheries, Animal Husbandry and Dairying, New Delhi, New Delhi, India \\ 3 Animal Biotechnology Centre, National Dairy Research Institute, Karnal, Haryana, India \\ 4 Animal Biotechnology Division, ICAR - National Bureau of Animal Genetic Resources, Karnal, Haryana, India \\ Corresponding Author: Vikas Vohra \\ Email address: Vikas.Vohra@icar.gov.in
}

To understand the similarities and dissimilarities of a breed structure among different buffalo breeds of North India, it is essential to capture their morphometric variation, genetic diversity, and effective population size. In the present study diversity among three important breeds, namely, Murrah, Nili-Ravi, and Gojri were studied using a parallel approach of morphometric characterization and molecular diversity. Morphology was characterized using 13 biometric traits, and molecular diversity through a panel of 22 microsatellite DNA markers recommended by FAO, Advisory Group on Animal Genetic Diversity, for diversity studies in buffaloes. Canonical discriminate analysis of biometric traits revealed different clusters suggesting distinct genetic entities among the three studied populations. Analysis of molecular variance revealed $81.8 \%$ of genetic variance was found within breeds, while $18.8 \%$ of the genetic variation was found between breeds. Effective population sizes estimated based on linkage disequilibrium were 142,75 , and 556 in Gojri, Nili-Ravi, and Murrah populations, respectively, indicated the presence of sufficient genetic variation and absence of intense selection among 3 breeds. The Bayesian approach of STRUCTURE analysis (at $K=3$ ) assigned all populations into 3 clusters with a degree of genetic admixture in the Murrah and Nili-Ravi buffalo populations. Admixture analysis reveals that the Murrah and Nili-Ravi while identified the Gojri as unique buffalo germplasm, indicating that there might be a common origin. The study provides important insights on buffalo breeds of North India that could be utilized in designing an effective breeding strategy, with an appropriate choice of breeds for upgrading local non-descript buffaloes along with conservation of unique germplasm. 
1 Morphometric and microsatellite-based comparative genetic diversity analysis in Bubalus

2

3

bubalis from North India

\section{Vikas Vohra $^{1 \dagger}$, Narendra Pratap Singh ${ }^{1}$, Supriya Chhotaray ${ }^{1}$, Varinder Singh Raina ${ }^{2}$, Alka} Chopra $^{3}$, and R.S. Kataria ${ }^{4}$

${ }^{1}$ Animal Genetics Breeding Division, ICAR-National Dairy Research Institute, Karnal-132001, Haryana, India.

${ }^{2}$ Consultant, Department of Animal Husbandry and Dairying, Ministry of Fisheries, Animal Husbandry and Dairying, New Delhi.

${ }^{3}$ Animal Biotechnology Centre, ICAR-National Dairy Research Institute, Karnal-132001, Haryana, India

${ }^{4}$ ICAR - National Bureau of Animal Genetic Resources, Karnal-132001, Haryana, India.

\section{Corresponding author:}

Dr. Vikas Vohra, Principal Scientist

Address: Animal Genetics Breeding Division, ICAR-National Dairy Research Institute, Karnal132001, Haryana, India

Email: Vikas.Vohra@icar.gov.in

vohravikas@gmail.com

\section{Abstract}

To understand the similarities and dissimilarities of a breed structure among different buffalo breeds of North India, it is essential to capture their morphometric variation, genetic diversity, and effective population size. In the present study diversity among three important breeds, namely, Murrah, Nili-Ravi, and Gojri were studied using a parallel approach of morphometric characterization and molecular diversity. Morphology was characterized using 13 biometric traits, and molecular diversity through a panel of 22 microsatellite DNA markers recommended by FAO, Advisory Group on Animal Genetic Diversity, for diversity studies in buffaloes. Canonical discriminate analysis of biometric traits revealed different clusters suggesting distinct genetic entities among the three studied populations. Analysis of molecular variance revealed $81.8 \%$ of 
30 genetic variance was found within breeds, while $18.8 \%$ of the genetic variation was found between

31 breeds. Effective population sizes estimated based on linkage disequilibrium were 142, 75, and

32556 in Gojri, Nili-Ravi, and Murrah populations, respectively, indicated the presence of sufficient

33 genetic variation and absence of intense selection among 3 breeds. The Bayesian approach of

34 STRUCTURE analysis (at $\mathrm{K}=3$ ) assigned all populations into 3 clusters with a degree of genetic

35 admixture in the Murrah and Nili-Ravi buffalo populations. Admixture analysis reveals that the

36 Murrah and Nili-Ravi while identified the Gojri as unique buffalo germplasm, indicating that there

37 might be a common origin. The study provides important insights on buffalo breeds of North India

38 that could be utilized in designing an effective breeding strategy, with an appropriate choice of

39 breeds for upgrading local non-descript buffaloes along with conservation of unique germplasm.

40 Keywords: Buffalo, Genetic Variation, India, Microsatellite Markers 


\section{Introduction}

43 Through the course of evolution, forces such as mutation, adaptation, reproductive isolation,

44 random drift, selection and breeding have created vast diversity (breeds) among the Bubalus

45 bubalis in India. Many well-defined breeds have been formed for various purposes and the high-

46 performance breeds are intensely selected worldwide. This has led to replacement of native low

47 performance breeds with high performance ones causing erosion of genetic resources (Groeneveld

48 et al., 2010). However, future trait of interests concerns the genetic diversity of low-performance

49 breeds so, that the population can be maintained for future breeding (Notter, 1999). The genetic

50 diversity of livestock species such as cattle, buffalo, pig, sheep, goat, camel and chicken have been

51 widely studied in several population and the diversity of zebu and taurine cattle breeds is one of

52 the most studied. Diversity between swamp and riverine buffaloes also have been studied using

53 microsatellite markers, mitochondrial D-loop and cytochrome b sequence variations (Barker et al.,

54 1997; Lau et al., 1998; Zhang et al., 2007).

55 Over the past few decades, world buffalo population has rapidly increased with 208 million

56 buffaloes in the world presently, having $96.79 \%$ of population in Asia, $1.68 \%$ in Africa, $1.23 \%$ in

57 the Americas and $0.22 \%$ in Europe (FAOSTAT, 2019). India alone has 109.85 million of buffalo

58 population with 17 registered breeds (20th All India Livestock Census, 2019). Water buffalo

59 (Bubalus Bubalis) that most probably domesticated in Indus Valley region for multiple utility

60 creates a rich Bubaline diversity in Northern regions of India, comprising states of Punjab,

61 Haryana, Himachal Pradesh, Delhi and Western Uttar Pradesh. The predominant bubaline genetic

62 resources documented from the region include Murrah, Nili Ravi and Gojri buffaloes

63 (http://www.nbagr.res.in/regbuf.html). Murrah being dominating buffalo germplasm with superior

64 milk-producing ability has suppressed the need for identification and characterization of other 
65 breeds. On the other hand, Gojri is one of the little-known buffalo population of the region, with a

66

67

68

69

70

71

72

73

74

75

76

77

78

79

80

81

82

83

84

85

good milch potential on low to zero input system of dairying and is maintained on a semi-migratory extensive system of management (Vohra et al., 2012 and 2015).

Characterization and classification of animal genetic resources (AnGR) require ample knowledge of the geographical distribution of the breeds, identification of unique characteristics, population size and structure, production environment, and genetic diversity. It is customary to perform a detailed molecular study along with physical and phenotypic assessment to check within and between population diversity in order to characterize a population (Weitzman, 1993; Hall \& Bradley, 1995; Barker, 1999; Ruane, 2000; Bruford et al., 2003; Simianer, 2005; Toro \& Caballero, 2005). Vohra et al. (2015) have used 13 morphometric traits of Gojri buffaloes for phenotypic characterization using Principal Component Analysis, a multivariate statistical technique. Multivariate statistical analysis techniques viz. classical principal component analysis serves the objectives of dimension reduction and clustering when multiple morphometric traits are measured (Johanson and Wichern, 2002; Yadav et al., 2017).

9 The neutrality, co-dominant inheritance and high polymorphic information content of microsatellite markers have rendered them as the markers of choice for diversity studies (Metta et al., 2004; Li et al., 2005; Yoon et al., 2005; Sodhi et al., 2005, 2006; Kumar et al., 2006; Pandey et al., 2006a; Pandey et al., 2006b; Vijh et al., 2008; Sharma et al., 2013). Several genetic diversity studies of water buffalo populations have been carried out throughout the world using microsatellite markers (Kataria et al., 2009; Ángel-Marín et al., 2010; Gargani et al., 2010; Mekkawy et al., 2012; Ünal et al., 2014; Vohra et al., 2017; Khade et al., 2019). 
86 The genetic diversity within Murrah, Nili-Ravi and Gojri breeds have been studied independently

87 that share the common breeding tract in North India. However, in India, buffalo breeding is largely

88 restricted to natural mating that subsequently may have led to admixture of these populations.

89 Hence, there is a need to assess the between-breed genetic diversity among these breeds. The

90 present study was performed to assess the levels of genetic diversity, and population structure

91 among three buffalo breeds of North India. The results will help in formulating an effective

92 breeding, management policy, shaping future conservation plans for maintaining breed purity and

93 reducing the possible admixture due to introgression among purebreds. Thus, it is imperative to

94 compare the region-specific diversity and breed status of bubaline germplasm.

95 Materials \& Methods

96 Sampling strategy

97 Sampling was done from their respective native tracts, to compare the genetic diversity between

98 three different breeds. Gojri buffalo samples were collected during 2017-18 from areas of Punjab

99 and Himachal Pradesh $\left(30^{0} 9^{\prime}\right.$ to $32^{\circ} 3^{\prime} \mathrm{N}$ and $75^{\circ}$ to $\left.77^{0} \mathrm{E}\right)$ states of India, and samples for Nili-

100 Ravi buffaloes were collected from Punjab state ( $28^{\circ} 17^{\prime}$ to $32^{\circ} 17^{\prime} \mathrm{N}$ and $74^{\circ}$ to $\left.76^{\circ} 41^{\prime} \mathrm{E}\right)$. The

101 Nili-Ravi has a comparatively smaller geographical distribution compared to Murrah and Gojri. In

102 India, Murrah buffaloes are found in almost all regions but its native area is Haryana state $\left(28^{0} 02^{\prime}\right.$

103 to $30^{0} 21^{\prime} \mathrm{N}$ and $75^{\circ}$ to $77^{\circ} \mathrm{E}$ ) hence, sampling was performed from Haryana and Punjab. The data

104 of Murrah and Nili-Ravi was taken for comparative analysis from Buffalo Genomics Lab of

105 National Bureau of Animal Genetic Resources, Karnal. The breeding and sampling tract had a herd

106 size of 2-6 buffaloes per households. To ensure that selected animals are unrelated, in the absence

107 of detailed pedigree accounts, buffalo breeders were interviewed in detail and their records were

108 checked. Only those animals who were not having common parents for at least 3-4 generations 
109 were included in the study. Buffaloes were selected for this study following guidelines of

110 measurement of domestic animal diversity program (FAO, 2011) those represented the original

111 indigenous true to type phenotype. Blood samples were collected with the consent of herd owners.

112 Approximately 5-10 $\mathrm{ml}$ of blood from jugular vein was collected by trained Veterinarian using

113 aseptic measures. All the studies were carried out under approval of ICAR-National Dairy

114 Research Institute IAEC 1705/GO/ac/13/CPCSEA.

115 Morphometric traits were measured on a total of 242 adult female buffaloes, comprising of 113

116 Murrah, 37 Nili-Ravi, and 92 Gojri buffaloes, to avoid the sex and age differences. Thirteen (13)

117 different traits were measured on all three breeds as suggested by Breno et al (2018). All the

118 measurements on the animal were recorded in their normal standing position on a levelled surface

119 using a tape measure by the same technical person. Traits recorded were body height (HT), body

120 length (BL), chest girth (CG), paunch girth (PG), face length (FL), face width (FW), horn length

121 (HL), horn circumference (HC), ear length (EL), distance between hip bone (HB), distance

122 between pin bone (PB), tail length (TL), and tail length up to switch (TS). To avoid age effects, 123 only adult buffaloes (3.5 years above) were included in study. For microsatellite genotyping, blood 124 samples were collected from 128 (40 Murrah, 40 Nili-Ravi, and 48 Gojri) buffaloes.

\section{Genotyping microsatellite markers}

126 Genomic DNA was isolated from blood samples by standard phenol-chloroform extraction 127 protocol, as described by Sambrook and Russel (2001). DNA concentration was checked by spectrophotometric method. Genetic variation was assayed using 25 microsatellite markers.

129 Microsatellite genotyping was carried out as previously describe in Vohra et al. (2017) following 130 the protocol of Mishra et al. (2010). Fluorescent-tagged forward primers for each microsatellite 
131 were used. The primers those were able to produce a fragment size $>75 \mathrm{bp}$ were used in the study.

132 Fragment length analysis was performed through ABI PRISM 3100 automatic sequencer (Applied

133 Biosystems, Foster City, CA, USA) after performing polymerase chain reaction (PCR) for 134 fragment amplification. Allele length for the different fragments generated was determined as 135 described in Vohra et al. (2017) using GeneScan software (version 5.0 Applied Bio system). 136 Observed number of alleles $\left(N_{\mathrm{a}}\right)$, theta estimate $\left(\theta_{\mathrm{H}}\right)$, expected heterozygosity $\left(H_{\mathrm{e}}\right), F_{\mathrm{IT}}$ (total 137 inbreeding estimate), $F_{\mathrm{ST}}$ (measurement of population differentiation) and $F_{\mathrm{IS}}$ (within- population138 inbreeding estimate) were calculated using Arlequin v3.5 (Excoffier et al., 2010). Pairwise 139 differences between populations using molecular distances were calculated. Molecular diversity 140 indices were calculated as per Tajima (1983), Tajima (1993), Nei (1987), and Zouros (1979), 141 implemented in Arlequin v3.5, and allowing 5\% level of missing data. Analysis of molecular 142 variances was done using 1,000 permutations. Exact test of population differentiation was 143 performed with 1,00,000 Markov chain steps and 10,000 dememorization steps.

\section{Statistical analysis}

145 Statistical analyses on morphometric data were performed using SPSS v17.0 software (SPSS, 146 2001). Multivariate analysis technique such as canonical discriminant analysis (CDA) 147 simultaneously analyse multiple correlated measurements in a single individual and increases the 148 discriminatory power by eliminating variables explaining less variation in the dataset. The relation 149 between the group the individual belongs to and a set of morphometric traits are quantified using 150 CDA (Zhao and Maclean, 2000). As, CDA provides optimum discrimination between population 151 to classify them as a different breed hence, widely used in breed characterization and genetic 152 diversity studies. 
153 The canonical discriminant analysis was performed in SAS v9.3 program (SAS Institute Inc., 2011)

154 using Proc disc procedure, for determining the most discriminatory morphometric traits. The

155 probabilities of assigning an individual to a population were determined using Discrim procedure

156 based on the linear discriminant function that included the thirteen morphometric variables. Wilk's

157 Lambda was used as the test statistics to check for the differences between the means of identified

158 groups of subjects on a combination of dependent variables.

159 Population assignment was performed using the Bayesian Markov chain Monte Carlo approach 160 implemented in Structure v2.3.4 (Pritchard et al., 2000). The Bayesian clustering algorithm 161 simultaneously estimates allele frequencies at each and individuals are assigned probabilistically 162 to one of the $K$ subpopulations. It assumes that prior distribution of population to which individuals 163 belong and allele frequencies are known.

164 The most likely number of subpopulations was determined by the Evanno $\Delta K$ method (Evanno et 165 al., 2005) using R package "POPHELPER” (Francis et al., 2017). Twenty independent runs were 166 performed for $K=2$ to 4 to identify the most likely number of clusters present in the dataset. The 167 analysis was performed with a burn in period of 10000 and 50000 MCMC iterations. Effective 168 population size $\left(N_{\mathrm{e}}\right)$ was checked for the three population. $N_{\mathrm{e}}$ was estimated using linkage 169 disequilibrium method using NeEstimator v2.01 (Do et al., 2014) Software. The $P$-critical value 170 (rare allele frequency) was set to 0.05 , below which all the alleles were rejected. Jackknife 171 confidence intervals (CI) were calculated for each estimate, $N_{\mathrm{e}}$, of different population. 172 Discrimination between populations was elucidated graphically through principal coordinate 173 analysis (PCoA) using Darwin v6.0.021 (Perrier et al., 2003). Principal coordinate analysis is a 174 classical multidimensional scaling method based on dissimilarity or distance matrix to assign each 
175 individual a location in a two or three-dimensional space. The dissimilarity matrix based

176 phylogenetic tree was also obtained through Darwin.

\section{Results}

\section{Classificatory analysis based on Morphometric traits}

179 The means and standard deviation, coefficient of variations and comparison of mean difference

180 between populations for each trait across population is listed in Table 1. A Canonical Discriminant analysis was used to compare different morphometric traits and first two canonical discriminant functions were used in the analysis, which explained $66.7 \%$ and $33.3 \%$ of total variance, respectively. Wilk's Lambda was used as the test statistics to check the difference between means of the two groups and was found to be significant (Table 2). Classification based on canonical discriminant functions for both original and cross-validated counts predicted $100 \%$ assignment of each adult buffaloes to their hypothetically known populations i.e. Murrah, Nili-Ravi, and Gojri. All the individuals plotted based on $1^{\text {st }}$ and $2^{\text {nd }}$ canonical discriminant functions were clustered into three distinct groups suggesting three different breeds in the sample (Fig. 1).

\section{Microsatellite variations}

Among 25 microsatellite loci genotyped for this study, only 22 loci that were polymorphic for all three populations were used for further downstream analysis. A total of 145, 138, and 173 alleles were found across 22 loci in the 128 individuals sampled from the Murrah, Nili-Ravi, and Gojri buffaloes, respectively. ILSTS60 was highly polymorphic in Gojri buffaloes, ILSTS95 in both Murrah and Nili-Ravi and ILSTS61 in Murrah (Fig. S1a). Mean number of alleles for all populations varied from $3.67 \pm 2.08$ at ILSTS19 to $10.33 \pm 0.58$ at CSSM47. Mean expected 
197 ILSTS58. The mean $H_{\mathrm{e}}$ estimated over all loci was lowest in Murrah $(0.58 \pm 0.25)$ while it was

198 highest in Gojri population $(0.70 \pm 0.15)$ (Fig. S1b). Estimator of mutation parameter $\left(\theta_{\mathrm{H}}\right)$ that is 199 obtained using observed homozygosity values was estimated under infinite allele model. Mean $\theta_{\mathrm{H}}$ 200 ranged from 1.36 in Murrah to 2.33 in Gojri buffaloes (Fig. S1c). Across all three populations mean $201 \theta_{\mathrm{H}}$ ranged from $0.17 \pm 0.03$ (ILSTS19) to $4.44 \pm 1.16$ (ILSTS58). Marker wise number of alleles, $H_{\mathrm{e}}$, 202 and $\theta_{\mathrm{H}}$ in each breed given in Table 3.

\section{Genetic diversity}

204 Global Analysis of molecular variance (AMOVA) using 19 polymorphic loci was accomplished. 205 Wright's F-statistics values obtained from the results of global AMOVA revealed 11.7\% deficit of 206 heterozygotes for each of the analyzed breeds $\left(F_{\text {IS }}\right)$ whereas the total population had a $27.8 \%$ deficit

207 of heterozygotes $\left(F_{\mathrm{IT}}\right)$. The average genetic differentiation $\left(F_{\mathrm{ST}}\right)$ between the breeds was $18.2 \%(p$ $208=0.00001)$ indicating significantly higher discrimination between breeds (Table 4). Details of 209 AMOVA results are presented in Table 4. The pair-wise $F_{\mathrm{ST}}$, Slatkin linearized $F_{\mathrm{ST}}$, and Nei's 210 distance (d) values were used to illustrate the genetic distance between breeds (Fig. 2a, 2b \& 2c), 211 which significantly differentiated all three breeds.

212 Murrah and Nili-Ravi population were clustered together while the Gojri population was present 213 as a distinct group, suggesting it as a different breed in factorial correspondence analysis (Fig. 3) 214 and phylogenetic tree (Fig. S2).

215 Effective population size $\left(N_{\mathrm{e}}\right)$ was estimated excluding rare alleles with an allele frequency below 216 0.05. The estimated effective population size of Gojri, Nili-Ravi, and, Murrah was found to be 142, 217 75, and 556, respectively. The Jack-knife CIs for the Ne estimates were 83-396, 48-141, and 136 218 to infinity for Gojri, Nili-Ravi, and Murrah, respectively at $0.05 P$-critical value of rare alleles. 


\section{Bayesian genetic structure}

220 Number of possible sub-populations estimated through Evanno $\Delta K$ method suggested a maximum

221 of three populations (Fig. 4). Population assignment accomplished in STRUCTURE for $K=2,3$, 222 and 4 and results are presented in the form of bar plot (Fig. 5). For $K=3$, as estimated through

223 Evanno $\Delta K$ method, it showed $99.4 \%$ of Gojri buffaloes are classified into their pre-defined breed.

$22495.9 \%$ of Nili-Ravi and 83.6\% of Murrah were assigned to their respective pre-defined groups.

225 Inferred ancestry of each individual (for $K=3$ ) along with average proportion of each individuals

226 classified into respective pre-assigned breeds (for $K=2,3$, and 4) is reported (Table 5).

\section{Discussion}

228

229

230

231

232

233

234

235

236

237

238

239

240

In India, limited work on complete characterization and classification of buffalo genetic resources have been carried out in past, primarily due to availability of much acclaimed Murrah buffaloes. The native breeding tract of Murrah buffalo is North India, and currently, more than $40 \%$ of the countries buffalo population is either Murrah or has been crossed with Murrah buffaloes. Hence, genetic studies on other buffalo populations is often neglected. However, several studies have been taken up on morphometric characterization of individual breeds yet there are limited reports on genetic diversity studies through molecular markers and comparative studies. A parallel approach of characterization and classification of buffalo germplasm in a region is much needed for genetic improvement in such populations. The present study is an evaluation of Riverine buffaloes of North India taking a geographical region-based approach.

\section{Morphological diversity}

Gojri animals with unique phenotypic appearance are quite distinct from Murrah, Murrah crosses, and Nili Ravi (Vohra et al., 2012). The average measurements for body biometric traits across the 
241 studied buffalo populations of the North India is listed in Table 1. Thirteen body biometric traits

242 across 3 population when compared, revealed significant differences among the studied

243 populations, except for FL and EL among Murrah and Gojri buffaloes, HC and HL between Nili-

244 Ravi and Gojri population. Body height (HT) and face width (FW) did not vary among Murrah and

245 Nili-Ravi populations. The comparison of morphometric traits between all three buffalo breeds of

246 the North India outlined the phenotypic distinctness for majority of the body biometric trait. The

247 coefficient of variation (CV) percentage was least for body height in all three breeds. On comparing

248 average of HT, BL, CG, and PG, Gojri buffaloes were found to be of smaller size than Murrah and

249 Nili-Ravi. Nivsarkar et al. (2000) in Nili-Ravi reported average HT, CG, and BL as 134.2, 207.7,

250 and $165.4 \mathrm{~cm}$, respectively, which is comparable to our results. CV\% was highest for HL in Gojri

$251(19.52 \%)$ and Murrah (12.61\%) buffaloes indicating lesser selection pressure on them and more

252 environmental influence. Face width (FW) was least variable in Murrah and Nili-Ravi while it

253 varied greatly in Gojri buffaloes. Most of the body biometric traits measured were less variable

254 indicating their reliability in population classification studies.

255 In the canonical discriminant analysis (refer to table 2), two functions were needed for separation

256 of three distinct population (Asamoah-Boaheng and Sam, 2016) and the first function (function 1)

257 explains $66.7 \%$ of the variance and has a Wilk's lambda $(0.008)$ with $p=0.0001$. The second

258 function explains only $33.3 \%$ of the variance in the data, with a recorded $p=0.0001$ for Wilk's

259 lambda (0.122). Wilks' Lambda value close to zero represents a greater number of variables

260 contribute to the discriminant function (Toalombo Vargas et al., 2019), thus the first function in

261 this study plays major role in classifying the breeds.

\section{Microsatellite variations and Genetic diversity}


263 Microsatellite marker data being the best-suited molecular information for the assessment of

264 genetic diversity (Bowcock et al., 1994; Laval et al., 2000; Groeneveld et al., 2010), allows future

265 management and conservation of the breeds based on their genetic architecture (Luikart et al.,

266 2003; Taberlet, et al., 2008; Toro et al., 2009; Teneva et al., 2013). The FAO and the ISAG/FAO

267 Advisory Group on Animal Genetic Diversity have proposed a panel of 25 SSR markers for

268 diversity studies in buffaloes (Singh et al., 2018). Hence, in the present study the 22 highly

269 polymorphic microsatellite markers out of 25 marker panel, were used for diversity analysis.

270 The mean number of alleles $\left(N_{\mathrm{a}}\right)$ in population over a range of loci is considered a fair indicator of

271 allelic variation. The mean $N_{\mathrm{a}}$ ranged from 0-10, 0-13, and 3-14 in Nili-Ravi, Murrah, and Gojri

272 buffaloes, respectively (refer to table 3). The mean $N_{\text {a }}$ per locus for each population in the present

273 study is similar to the reports of Kathiravan et al. (2010) in South Kanara buffaloes; Marques et al.

274 (2011) in Brazilian buffaloes, Martinez et al. (2006), Bhuyan et al. (2010) in Murrah buffaloes and

275 Sajid Ali et al. (2020) in Purnathadi buffaloes. However, a higher number of alleles per locus

276 ranged from 11-26 alleles in Indian water buffaloes have been reported by Vijh et al. (2008). The

277 type of breed under investigation, usage of the particular panel of microsatellite markers, methods

278 of genotyping and the genetic polymorphism within the breed itself greatly influence this variation

279 in the $N_{\mathrm{a}}$.

280 For microsatellite data, Ohta and Kimura (1973) have established the relationship between the

281 expected homozygosity and its estimator $\theta$, under a pure stepwise mutation model i.e. expected

282 homozygosity $=1 / \sqrt{1+2 \theta}$. An estimator of $\theta$ can be obtained from microsatellite data by applying

283 the formula, $\theta_{\mathrm{H}}=\left[1 /\left(1-H_{\mathrm{e}}\right)^{2}-1\right]\left(\right.$ Excoffier et al., 2010), where $H_{\mathrm{e}}$ is the expected heterozygosity.

284 The mean $H_{\mathrm{e}}$ ranging from 0.14 to 0.81 across all three population over all loci (refer to table 3 ) is

285 indicative of sufficient polymorphism to measure genetic variation (Takezaki and Nei, 1996). In

Peer] reviewing PDF | (2021:04:59778:2:0:NEW 28 Jun 2021) 
286 Gojri buffaloes the expected heterozygosity $\left(H_{\mathrm{e}}\right)$ ranged from 0.12 to 0.82 that was comparable

287 with the results reported by Singh et al. (2019). While in both Murrah and Nili-Ravi, it ranged from

2880 to 0.81 (refer to table 3). Similar high overall mean $H_{\mathrm{e}}$ were reported in Pandharpuri (Khade et

289 al., 2019), Mehsana (Jakhesara et al., 2010), Egyptian (Attia et al., 2014) and Purnathadi (Sajid Ali

290 et al., 2020) buffaloes. The substantially high $H_{\mathrm{e}}$ values implies the presence of high genetic

291 variability in the studied buffalo breeds and suitability of the marker panel for the present study.

292 The average $\mathrm{F}$ statistics over 19 loci were $F_{I S}=0.11744, F_{S T}=0.18252$ and $F_{I T}=0.27852$ (refer to

293 table 4). In the present study, considerable degree of differentiation has been estimated compared

294 to other buffalo populations from different regions, probably because these populations are 295 genetically distinct. Joshi et al. (2012) reported an $F_{\mathrm{ST}}$ value of 7.2\% in buffaloes of Indo-gangetic

296 plain, while Vijh et al. (2008) reported a value of 9.69\%. However, a comparatively lesser value

297 in eight Indian riverine buffalo was reported by Kumar et al. (2006) which was 3.4\%. This value

298 suggested the existence of greater genetic differentiation among North-Indian buffalo breeds than

299 breeds found all over India. A heterozygote deficiency was evident from the positive mean $F_{\text {IS }}$

300 value $(0.117>0)$ indicating low to moderate amount of inbreeding in the population. This could be

301 attributed to assortative mating in small herds owned by farmers, genetic hitchhiking, or the null

302 alleles (Mishra et al., 2008). However, AMOVA over all 22 loci showed 23.59\% of variations

303 between populations suggesting the distinctness of all three breeds. The $F_{\text {IS }}$ value was found to be

304 4.74\%, which is comparable to values obtained in Purnathadi buffaloes (Sajid Ali et al., 2020).

305 The pair-wise $F_{\text {ST }}$ values ranged from 0.09 between Murrah and Nili-Ravi to 0.32 between Nili-

306 Ravi and Gojri breeds. The $F_{\mathrm{ST}}$ between Murrah and Gojri was 0.25 (Fig. 2a). Least differentiation

307 was found between Nili-Ravi and Murrah (0.09) based on Slatkin linearized $F_{\mathrm{ST}}$ while it was

308 highest between Nili-Ravi and Gojri (0.46). Between Murrah and Gojri it was found to be 0.33 
309 (Fig. 2b). Nei's distance (d); average within and between populations differentiation is presented

310 in the form of a heat map (Fig. 2c), that shows least distance between Murrah and Nili-Ravi breeds

311 and discriminate Gojri as another population. These results were also in compliance with the results

312 from the factorial correspondence analysis based on molecular data and phylogenetic tree obtained

313 from dissimilarity matrix. In the scatter plot of factorial analysis, Murrah and Nili-Ravi are

314 invariably clustered together. Meanwhile, Gojri was found to be plotted on the opposite side of

315 axis-2 (Fig. 3), yet with more scattering among individuals.

316 The linkage disequilibrium method relies on measures of departure from expected genotype and

317 gametic frequencies, which is the basis for estimation of effective population size (Hill, 1981;

318 Waples, 1991; Luikart et al., 2010). The $N_{\mathrm{e}}$ estimated from microsatellite data reflects the true

319 population distribution of North Indian buffaloes. The comparatively higher $N_{\mathrm{e}}$ of Murrah

320 buffaloes is due to the larger population distribution of the breed in India. The $N_{\mathrm{e}}$ estimates of Gojri

321 population reflects its present status and probable serious inbreeding in future. Hence, the ongoing

322 indiscriminate breeding practices should be shifted to implementation of organized breeding 323 policies focussed on conservation of this distinct breed.

\section{Bayesian genetic structure}

325 Structure software (Pritchard et al., 2000) was used to determine the unbiased structure assuming 326 no prior knowledge regarding the number of breeds. The highest delta $K(\Delta K)$ value was calculated 327 as previously described (Evanno et al., 2005). The optimum $\Delta K$ value (Fig. 4), was found at $K=$ 3. For $K=2$, there was no differentiation between Nili-Ravi and Murrah breed. One individual from

329 Murrah population showed significant level of admixture from Gojri population. 99.7\% of Gojri 330 buffaloes were classified as a different breed whereas $99.7 \%$ and $98.9 \%$ of Nili-Ravi and Murrah 
331 buffaloes were assigned to one single population, respectively. When $K$ is assumed to be four,

332 Gojri buffaloes are assigned to one distinct cluster with $99 \%$ of memberships. Structure assigned

333 all three population into three different breeds when $K$ was assumed to be three (Fig. 5). This

334 indicated that studied populations has well differentiated and possess unique allelic combinations

335 despite being reared in similar geographical regions. However, a low to moderate amount of

336 admixture could be observed in both Murrah and Nili-Ravi population. For $K=3$, Nili-Ravi showed

337 an average admixture of 3.7\% from Murrah and $0.4 \%$ from Gojri buffaloes while it was quite high

338 for Murrah with an average admixture of 15.2 and 1.2\% from Nili-Ravi and Gojri, respectively.

339 While Gojri population was found to have $99.4 \%$ pure blood with an admixture of $0.3 \%$ from Nili-

340 Ravi and $0.4 \%$ from Murrah. Our results indicate the presence of sufficiently large genetic

341 variability among the North Indian Riverine buffaloes. However, Gojri buffalo populations is

342 unique, compared to Murrah and Nili Ravi buffalos, which were found to be genetically closer

343 than expected. Presently the breeding areas of all these populations are overlapping due to adoption

344 of Murrah as an improver breed for milk production, thus leading to its dominance over Nili-Ravi

345 and Gojri buffalo.

\section{Conclusion}

347 This study demonstrated that the characterization and classification of genetic diversity in Indian

348 buffaloes could be better accomplished through a parallel approach comprising morphometric

349 traits and microsatellite markers. Study of buffalo genetic diversity of Northern India revealed

350 admixture of two major dairy buffalo breeds and a distinct buffalo population was identified. The

351 results obtained provides an opportunity for the design of genetic improvement programs with

352 appropriate choice of breeds for upgrading local non-descript buffaloes along with conservation of

353 unique germplasm. The estimates of effective population size and fixation indices indicate absence 
354 of intense systematic selection in past. Further studies involving large populations including

355 samples from other regions of Indian buffalo with FAO recommended microsatellite loci are

356 required to understand the genetic relationships among buffalo genetic resource of India.

\section{Acknowledgement}

358 The authors thank the Directors of ICAR-NDRI and ICAR-NBAGR for their support to carry out

359 the study. Technical support received from Mr. Subhash Chander, T-5, NBAGR, is gratefully 360 appreciated.

361

362

363

364

365

366

367

368

369

370

371

372

373

374

\section{References:}

1. Ali, S. S., Kuralkar, S. V., Das, R., Raina, V., Kataria, R. S. \& Vohra, V. (2020). Assessment of genetic diversity and bottleneck in Purnathadi buffaloes using short tandem repeat markers. Animal Biotechnology, 1-12.

2. Ángel-Marín, P. A., Cardona, H., Moreno-Ochoa, M., \& Cerón-Muñoz, M. F. (2010). Analysis of genetic diversity in Colombian buffalo herds. Revista Colombiana de Ciencias Pecuarias 23(4), 411-421.

3. Asamoah-Boaheng, M. \& Sam, E. K. (2016). Morphological characterization of breeds of sheep: a discriminant analysis approach. SpringerPlus 5(1), 69.

4. Attia, M., Abou-Bakr, S. \& Hafez, Y. M. Genetic polymorphism of seven microsatellite DNA markers in Egyptian buffalo. Animal Biotechnology (Cattles, Buffalo) 7 (12), 7.

5. Barker, J. S. F. (1999). Conservation of livestock breed diversity. Animal Genetic Resources/Resources génétiques animales/Recursos genéticos animals 25, 33-43.

6. Barker, J. S. F., Tan, S. G., Selvaraj, O. S., \& Mukherjee, T. K. (1997). Genetic variation within and relationships among populations of Asian water buffalo (Bubalus bubalis). Animal Genetics 28(1) 1-13. 
7. Bhuyan, D.K., Sangwan, M.L., Gole, V.C. \& Sethi, R.K. (2010). Studies on DNA fingerprinting in Murrah buffaloes using microsatellite markers. http://nopr.niscair.res.in/handle/123456789/10433

8. Bowcock, A. M., Ruiz-Linares, A., Tomfohrde, J., Minch, E., Kidd, J. R. \& Cavalli-Sforza, L. L. (1994). High resolution of human evolutionary trees with polymorphic microsatellites. Nature 368(6470), 455-457.

9. Breno Araújo de Melo, Isabele de Melo Nascimento, Lays Thayse Alves dos Santos, Luciano Gomes de Lima, Filipe Chagas Teodózio de Araújo, Raisa Rodrigues Santos Rios, Alberto de Gusmão Couto \& Angelina Bossi Fraga (2018). Body morphometric measurements in Murrah crossbred buffaloes (Bubalus bubalis). Journal of Applied Animal Research 46:1. 1307-1312. DOI: 10.1080/09712119.2018.1502669

10. Bruford, M. W., Bradley, D. G. \& Luikart, G. (2003). DNA markers reveal the complexity of livestock domestication. Nature Reviews Genetics 4(11), 900.

11. Do, C., Waples, R. S., Peel, D., Macbeth, G. M., Tillett, B. J. \& Ovenden, J. R. (2014). NeEstimator v2: re-implementation of software for the estimation of contemporary effective population size (Ne) from genetic data. Molecular ecology resources 14(1), 209214.

12. Evanno, G., Regnaut, S. \& Goudet, J. (2005). Detecting the number of clusters of individuals using the software STRUCTURE: a simulation study. Molecular ecology 14(8), 2611-2620.

13. Excoffier, L., \& Lischer, H. E. (2010). Arlequin suite ver 3.5: a new series of programs to perform population genetics analyses under Linux and Windows. Molecular ecology resources $\mathbf{1 0}(3), 564-567$. 
401

402

403

404

405

406

407

408

409

410

411

412

413

414

415

416

417

418

419

420

421

422

423

14. FAO (2011). Molecular genetic characterization of animal genetic resources. In: FAO Animal Production and Health Guidelines. No. 9, Rome.

15. FAO (2012). Phenotypic characterization of animal genetic resources. In: FAO Animal Production and Health Guidelines No. 11, Rome. Available at: http://www.fao.org/3/ai2686e.pdf

16. FAO_Food and Agricultural Organization of the United Nations. FAOSTAT. FAO Statistics Division. (2019). Available online: http://www.fao.org/faostat/en/\#data/QA

17. Francis, R. M. (2017). pophelper: an R package and web app to analyse and visualize population structure. Molecular ecology resources, 17(1), 27-32.

18. Gargani, M., Pariset, L., Soysal, M. I., Özkan, E., \& Valentini, A. (2010). Genetic variation and relationships among Turkish water buffalo populations. Animal genetics 41(1), 93-96.

19. Groeneveld, L.F., Lenstra, J.A., Eding, H., Toro, M.A., Scherf, B., Pilling, D., Negrini, R., Jianlin, H., Finlay, E.K., Groeneveld, E. \& Weigend S. (2010). Genetic diversity in livestock breeds. Animal Genetics 41(Suppl 1), 6-31.

20. Groeneveld, L.F., Lenstra, J.A., Eding, H., Toro, M.A., Scherf, B., Pilling, D., Negrini, R., Finlay, E.K., Jianlin, H., Groeneveld, E.J.A.G. and Weigend, S., 2010. Genetic diversity in farm animals-a review. Animal genetics 41, 6-31.

21. Hall, S. J. \& Bradley, D. G. (1995). Conserving livestock breed biodiversity. Trends in ecology \& evolution 10(7), 267-270.

22. Hill, W. G. (1981). Estimation of effective population size from data on linkage disequilibrium. Genetics Research 38(3), 209-216.

23. Jakhesara, S. J., Rank, D. N., Kansara, J. D., Parikh, R. C., Vataliya, P. H. \& Solanki, J. V. (2010). Microsatellite DNA typing for assessment of genetic variability in the Mehsana 

1084 BANGKOK 10903, THAILAND 29(4), 262.

24. Jakobsson, M. \& Rosenberg, N. A. (2007). CLUMPP: a cluster matching and permutation program for dealing with label switching and multimodality in analysis of population structure. Bioinformatics 23, 1801-1806.

25. Johnson, R. A. \& Wichern, D. W. (2002). Applied multivariate statistical analysis, Upper Saddle River, NJ: Prentice hall 5(8).

26. Kataria, R. S., Sunder, S., Malik, G., Mukesh, M., Kathiravan, P., \& Mishra, B. P. (2009). Genetic diversity and bottleneck analysis of Nagpuri buffalo breed of India based on microsatellite data. Russian journal of genetics 45(7), 826-832.

27. Kathiravan, P., Mishra, B. P., Kataria, R. S., Goyal, S., Tripathy, K. \& Sadana, D. K. (2010). Short tandem repeat based analysis of genetic variability in Kanarese buffalo of South India. Russian journal of genetics 46(8), 988-993.

28. Khade, K. A., Panigrahi, M., Ahmad, S. F., Kumar, P. \& Bhushan, B. (2019). Genetic characterization and assessment of diversity in Pandharpuri buffalo breed of India using heterologous microsatellite markers. Animal biotechnology, 1-6.

29. Kumar, S., Gupta, J., Kumar, N., Dikshit, K., Navani, N., Jain, P. \& Nagarajan, M. (2006). Genetic variation and relationships among eight Indian riverine buffalo breeds. Molecular ecology 15(3), 593-600.

30. Lau, C. H., Drinkwater, R. D., Yusoff, K., Tan, S. G., Hetzel, D. J. S., \& Barker, J. S. F. (1998). Genetic diversity of Asian water buffalo (Bubalus bubalis): mitochondrial DNA D-loop and cytochrome b sequence variation. Animal Genetics 29(4) 253-264. 
446

447

448

449

450

451

452

453

454

455

456

457

458

459

460

461

462

463

464

465

466

467

468

31. Laval, G., Iannuccelli, N., Legault, C., Milan, D., Groenen, M. A., Giuffra, E. \& Geldermann, H. (2000). Genetic diversity of eleven European pig breeds. Genetics selection evolution 32(2), 187.

32. Li, M. H., Nogovitsina, E., Ivanova, Z., Erhardt, G., Vilkki, J., Popov, R. \& Kantanen, J. (2005). Genetic contribution of indigenous Yakutian cattle to two hybrid populations, revealed by microsatellite variation. Asian-australasian journal of animal sciences 18(5), 613-619.

33. Luikart, G., England, P. R., Tallmon, D., Jordan, S. \& Taberlet, P. (2003). The power and promise of population genomics: from genotyping to genome typing. Nature reviews genetics 4(12), 981-994.

34. Luikart, G., Ryman, N., Tallmon, D. A., Schwartz, M. K. \& Allendorf, F. W. (2010). Estimation of census and effective population sizes: the increasing usefulness of DNAbased approaches. Conservation Genetics 11(2), 355-373.

35. Marques, J. R. F., Martínez, A. M., Costa, M. R., Albuquerque, M. S. M., Quiroz, J., Plá, J. L. V. \& Bermejo, J. V. D. (2011). Genetic diversity of Brazilian buffaloes (Bubalus bubalis) using DNA microsatellites. Archivos de zootecnia 60(232), 1213-1221.

36. Martínez, E., Tirado, J. F., Cerón-Muñoz, M. F., Moreno, M., Montoya, A., Corrales, J. D. \& Calvo, S. J. (2009). Genetic characterization of Murrah Buffalo breed in Colombia using microsatellite DNA markers. Livestock Research for Rural Development 21(1).

37. Mekkawy, W., Hafez, Y. M., Attia, M., Abdel-Salam, S. A. M., \& Abou-Bakr, S. (2012). Association analysis between microsatellite DNA markers and milk yield and its components in Egyptian buffaloes using random regression model. Egyptian Journal of Animal Production 49(1), 9-18. 
469

470

471

472

473

474

475

476

477

478

479

480

481

482

483

484

485

486

487

488

489
38. Metta, M., Kanginakudru, S., Gudiseva, N. \& Nagaraju, J. (2004). Genetic characterization of the Indian cattle breeds, Ongole and Deoni (Bos indicus), using microsatellite markers-a preliminary study. BMC genetics $\mathbf{5}(1), 16$.

39. Ministry of Agriculture and Farmers Welfare, GoI. 19th Livestock Census Report. New Delhi, India: Department of Animal Husbandry DAHDF; 2012.

40. Mishra, B. P., Kataria, R. S., Bulandi, S. S., Kumar, V. \& Mukesh, M. (2008). Genetic diversity in river buffalo (Bubalus bubalis) breeds of central India using heterologous bovine microsatellite markers. Journal of Applied Animal Research 33(2), 159-163.

41. Mishra, B.P., Kataria, R.S., Kathiravan, P., Singh, K.P., Sadana, D.K. \& Joshi, B.K. (2010). Microsatellite based genetic structuring reveals unique identity of Banni among river buffaloes of Western India. Livestock Science 127(2-3), 257-261

42. Nei, M. (1987). Molecular evolutionary genetics. Columbia university press, New York, NY, USA.

43. Nivsarkar, A.E., Vij, P.K. \& Tantia, M.S. (2000). Animal genetic resources of India: Cattle and Buffalo. Directorate of information and publications of Agriculture, ICAR, New Delhi, India.

44. Notter, D. R. (1999). The importance of genetic diversity in livestock populations of the future. Journal of animal science 77(1), 61-69.

45. Ohta, T. \& Kimura, M. (1973). A model of mutation appropriate to estimate the number of electrophoretically detectable alleles in a finite population. Genetics Research 22(2), 201204. 
490

491

492

493

494

495

496

497

498

499

500

501

502

503

504

505

506

507

508

509

510

511

512
46. Özkan Ünal, E., Soysal, M. İ., Yüncü, E., Dağtaş, N. D., \& Togan, İ. (2014). Microsatellite based genetic diversity among the three water buffalo (Bubalus bubalis) populations in Turkey. Archives Animal Breeding 57(1), 1-12.

47. Pandey, A. K., Sharma, R., Singh, Y., Prakash, B. \& Ahlawat, S. P. S. (2006). Evaluation of genetic variability in Kenkatha cattle by microsatellite markers. Asian-australasian journal of animal sciences 19(12), 1685-1690.

48. Pandey, A. K., Sharma, R., Singh, Y., Prakash, B. B. \& Ahlawat, S. P. S. (2006). Genetic diversity studies of Kherigarh cattle based on microsatellite markers. Journal of genetics 85(2), 117-122.

49. Perrier, X., Flori, A. \& Bonnot, F. (2003). Data analysis methods In: Hamon P, Seguin M, Perrier X, Glaszmann JC Ed, Genetic diversity of cultivated tropical plants.

50. Pritchard, J. K., Stephens, M. \& Donnelly, P. (2000). Inference of population structure using multilocus genotype data. Genetics 155(2), 945-959.

51. Ruane, J. (2000). A framework for prioritizing domestic animal breeds for conservation purposes at the national level: a Norwegian case study. Conservation Biology 14(5), 13851393.

52. Sambrook, J. \& Russel, D.W. (2001). Molecular Cloning, Animal Laboratory manual. Cold Spring Harbor Laboratory press, Cold spring Harbor, New York.

53. Sharma, R., Maitra, A., Singh, P. K. \& Tantia, M. S. (2013). Genetic diversity and relationship of cattle populations of East India: distinguishing lesser known cattle populations and established breeds based on STR markers. SpringerPlus 2(1), 359.

54. Simianer, H. (2005). Decision making in livestock conservation. Ecological Economics 53(4), 559-572. 
513 55. Singh, N. P., Vohra, V., Das, R., Verma, U., Tantia, M. S. \& Kataria, R. S. (2019).

514 Elucidating the genetic diversity using SSR based markers in Gojri buffalo. Indian Journal $515 \quad$ of Animal Sciences 89(5), 522-527.

516 56. Singh, N. P., Yadav, V., Raina, V., Prakah, R., Pal, S. S. \& Baranwal, A. (2018).

517 Heterologous microsatellite markers/SSR used in buffaloes species. Journal of $518 \quad$ Pharmacognosy and Phytochemistry 7(4), 267-271.

519 57. Sodhi, M., Mukesh, M., Mishra, B. P., Prakash, B., Ahlawat, S. P. S. \& Mitkari, K. R. 520 (2005). Evaluation of genetic differentiation in Bos indicus cattle breeds from Marathwada region of India using microsatellite polymorphism. Animal biotechnology 16(2), 127-137. 58. SPSS. 2001. Statistical Package for Social Sciences. SPSS Inc., 444 Michigan Avenue, Chicago, IL 60611.

59. Tajima, F. (1983). Evolutionary relationship of DNA sequences in finite populations. Genetics $\mathbf{1 0 5}(2), 437-460$.

60. Tajima, F. (1993). Measurement of DNA polymorphism. Mechanisms of Molecular Evolution, In: Introduction to Molecular Paleopopulation Biology, 37-59.

61. Takezaki, N. \& Nei, M. (1996). Genetic distances and reconstruction of phylogenetic trees from microsatellite DNA. Genetics, 144(1), 389-399.

62. Tantia, M. \& Vijh, R. (2012). Microsatellite analysis of buffaloes of Indo-Gangetic Plains. Indian Journal of Animal Sciences 82(11), 1434-1437.

63. Teneva, A., Dimitrov, K., Caro Petrović, V., Petrović, M. P., Dimitrova, I., Tyufekchiev, N. \& Petrov, N. (2013). Molecular genetics and SSR markers as a new practice in farm animal genomic analysis for breeding and control of disease disorders. Biotechnology in Animal Husbandry 29(3), 405-429. 
536

537

538

539

540

541

542

543

544

545

546

547

548

549

550

551

552

553

554

555

556

557
64. Toalombo Vargas, P. A., León, J. M., Fiallos Ortega, L. R., Martinez, A., Villafuerte Gavilanes, A. A., Delgado, J. V. \& Landi, V. (2019). Deciphering the Patterns of Genetic Admixture and Diversity in the Ecuadorian Creole Chicken. Animals 9(9), 670.

65. Toro, M. \& Caballero, A. (2005). Characterization and conservation of genetic diversity in subdivided populations. Philosophical Transactions of the Royal Society of London, Series B: Biological Sciences 360, 1367-78.

66. Toro, M. A., Fernández, J. \& Caballero, A. (2009). Molecular characterization of breeds and its use in conservation. Livestock Science 120(3), 174-195.

67. Vijh, R. K., Tantia, M. S., Mishra, B. \& Bharani Kumar, S. T. (2008). Genetic relationship and diversity analysis of Indian water buffalo (Bubalus bubalis). Journal of animal science 86(7), 1495-1502.

68. Vohra, V., Niranjan, S. K. \& Joshi, B. K. (2012). Gojri-A novel migratory buffalo germplasm in Punjab and Himachal Pradesh. Journal of Animal Research 2(3), 317-321.

69. Vohra, V., Niranjan, S. K., Mishra, A. K., Jamuna, V., Chopra, A., Sharma, N. \& Jeong, D. K. (2015). Phenotypic characterization and multivariate analysis to explain body conformation in lesser known buffalo (Bubalus bubalis) from North India. AsianAustralasian journal of animal sciences 28(3), 311.

70. Vohra, V., Sodhi, M., Niranjan, S. K., Mishra, A. K., Chopra, A., Kumar, M. and Joshi A K. (2017) Characterization of rare migratory cattle and evaluation of its phylogeny using short-tandem-repeat-based markers. Journal of Applied Animal Research 45(1): 355-363

71. Waples, R. S. (1991). Genetic methods for estimating the effective size of cetacean populations. Report of the International Whaling Commission (special issue) 13, 279-300. 
558

559

560

561

562

563

564

565

566

567

568

569

570

571

572

573

72. Weitzman, M. L. (1993). What to preserve? An application of diversity theory to crane conservation. The Quarterly Journal of Economics 108(1), 157-183.

73. Yadav, D. K., Arora, R. \& Jain, A. (2017). Classification and conservation priority of five Deccani sheep ecotypes of Maharashtra, India. PloS one 12(9).

74. Yoon, D. H., Kong, H. S., Oh, J. D., Lee, J. H., Cho, B. W., Kim, J. D. \& Lee, H. K. (2005). Establishment of an individual identification system based on microsatellite polymorphisms in Korean cattle (Hanwoo). Asian-australasian journal of animal sciences 18(6), 762-766.

75. Zhang, Y., Sun, D., Yu, Y., \& Zhang, Y. (2007). Genetic diversity and differentiation of Chinese domestic buffalo based on 30 microsatellite markers. Animal Genetics 38(6), 569575.

76. Zhao, G., \& Maclean, A. L. (2000). A comparison of canonical discriminant analysis and principal component analysis for spectral transformation. PE\&RS, Photogrammetric Engineering \& Remote Sensing 66(7), 841-847.

77. Zouros, E. (1979). Mutation rates, population sizes and amounts of electrophoretic variation of enzyme loci in natural populations. Genetics 92(2), 623-646. 


\section{Table 1 (on next page)}

Average measurements of body morphometric traits in 3 buffalo populations from Northern India

Pop, Mu, NR, Goj in the table corresponds to 'Population', 'Murrah', 'Nili-Ravi' and 'Gojri', respectively. * The mean difference is significant at the 0.05 level. 
1

2

\begin{tabular}{|c|c|c|c|c|c|c|c|c|c|c|}
\hline $\begin{array}{c}\text { Traits } \\
\text { (measured in } \\
\text { cm) }\end{array}$ & Pop & Mean \pm SE & SD & Min. & Max. & CV\% & $\begin{array}{l}\text { Pop } \\
\text { (i) }\end{array}$ & $\begin{array}{c}\text { Pop } \\
\text { (j) }\end{array}$ & $\begin{array}{c}\text { Mean } \\
\text { Difference } \\
(\mathbf{i}-\mathbf{j})\end{array}$ & $p$-value \\
\hline \multirow{3}{*}{ Body Height } & $\mathrm{Mu}$ & $138.40 \pm 0.41$ & 4.40 & 129.00 & 150.00 & 3.17 & $\mathrm{Mu}$ & NR & $4.29 \pm 0.85$ & 0.095 \\
\hline & NR & $134.10 \pm 1.10$ & 4.79 & 108.00 & 134.00 & 4.35 & $\mathrm{Mu}$ & Goj & $9.58 * \pm 0.63$ & 0.0001 \\
\hline & Goj & $128.82 \pm 0.47$ & 4.51 & 118.00 & 145.00 & 3.49 & NR & Goj & $-5.28 * \pm 0.88$ & 0.0001 \\
\hline \multirow{3}{*}{ Body Length } & $\mathrm{Mu}$ & $129.26 \pm 0.55$ & 5.85 & 115.00 & 147.00 & 4.52 & $\mathrm{Mu}$ & NR & $23.45^{*} \pm 1.08$ & 0.0001 \\
\hline & NR & $105.81 \pm 1.12$ & 6.83 & 91.00 & 121.00 & 6.45 & $\mathrm{Mu}$ & Goj & $-4.22 * \pm 0.80$ & 0.0001 \\
\hline & Goj & $133.48 \pm 0.51$ & 4.90 & 122.00 & 151.00 & 3.67 & $\mathrm{NR}$ & Goj & $-27.67 * \pm 1.11$ & 0.0001 \\
\hline \multirow{3}{*}{ Chest Girth } & $\mathrm{Mu}$ & $212.53 \pm 1.12$ & 11.87 & 185.00 & 250.00 & 5.58 & $\mathrm{Mu}$ & NR & $51.37 * \pm 2.01$ & 0.0001 \\
\hline & NR & $161.16 \pm 1.52$ & 9.27 & 144.00 & 182.00 & 5.74 & $\mathrm{Mu}$ & Goj & $16.63 * \pm 1.49$ & 0.0001 \\
\hline & Goj & $195.90 \pm 0.98$ & 9.43 & 170.00 & 214.00 & 4.81 & NR & Goj & $-34.74 * \pm 2.07$ & 0.0001 \\
\hline \multirow{3}{*}{ Paunch Girth } & $\mathrm{Mu}$ & $232.11 \pm 1.09$ & 11.54 & 208.00 & 266.00 & 4.97 & $\mathrm{Mu}$ & NR & $60.84 * \pm 2.84$ & 0.0001 \\
\hline & NR & $171.27 \pm 1.79$ & 10.89 & 153.00 & 198.00 & 6.35 & $\mathrm{Mu}$ & Goj & $18.91 * \pm 2.11$ & 0.0001 \\
\hline & Goj & $213.20 \pm 2.03$ & 19.50 & 121.00 & 242.00 & 9.14 & NR & Goj & $-41.92 * \pm 2.92$ & 0.0001 \\
\hline \multirow{3}{*}{ Face Length } & $\mathrm{Mu}$ & $49.29 \pm 0.25$ & 2.61 & 46.00 & 62.00 & 5.27 & $\mathrm{Mu}$ & $\mathrm{NR}$ & $8.40 * \pm 0.41$ & 0.0001 \\
\hline & NR & $40.89 \pm 0.31$ & 1.88 & 38.00 & 46.00 & 4.60 & $\mathrm{Mu}$ & Goj & $0.66 \pm 0.31$ & $\underline{0.081}$ \\
\hline & Goj & $48.63 \pm 0.17$ & 1.66 & 44.00 & 54.00 & 3.41 & NR & Goj & $-7.74 * \pm 0.43$ & 0.0001 \\
\hline \multirow{3}{*}{ Face Width } & $\mathrm{Mu}$ & $19.72 \pm 0.09$ & 0.98 & 18.00 & 22.00 & 4.92 & $\mathrm{Mu}$ & NR & $-0.15 \pm 0.51$ & 0.955 \\
\hline & NR & $19.86 \pm 0.19$ & 1.18 & 18.00 & 23.00 & 5.95 & $\mathrm{Mu}$ & Goj & $-3.29 * \pm 0.38$ & 0.0001 \\
\hline & Goj & $23.01 \pm 0.43$ & 4.17 & 20.00 & 49.00 & 18.10 & NR & Goj & $-3.15^{*} \pm 0.53$ & 0.0001 \\
\hline \multirow{3}{*}{ Ear Length } & $\mathrm{Mu}$ & $28.41 \pm 0.11$ & 1.22 & 25.00 & 30.00 & 4.29 & $\mathrm{Mu}$ & NR & $7.92 * \pm 0.23$ & 0.0001 \\
\hline & NR & $20.49 \pm 0.17$ & 1.04 & 19.00 & 22.00 & 5.09 & $\mathrm{Mu}$ & Goj & $-0.30 \pm 0.17$ & $\underline{0.110}$ \\
\hline & Goj & $28.75 \pm 0.13$ & 1.25 & 21.00 & 31.00 & 4.34 & NR & Goj & $-8.26 * \pm 0.24$ & 0.0001 \\
\hline \multirow{3}{*}{ Horn Length } & $\mathrm{Mu}$ & $28.37 \pm 0.34$ & 3.59 & 16.00 & 34.00 & 12.61 & $\mathrm{Mu}$ & NR & $-17.84 * \pm 1.19$ & 0.0001 \\
\hline & NR & $46.22 \pm 0.88$ & 5.32 & 34.00 & 56.00 & 11.51 & $\mathrm{Mu}$ & Goj & $-16.36 * \pm 0.88$ & 0.0001 \\
\hline & Goj & $44.73 \pm 0.91$ & 8.73 & 23.00 & 82.00 & 19.52 & NR & Goj & $1.49 \pm 1.22$ & $\underline{0.443}$ \\
\hline \multirow{3}{*}{$\begin{array}{l}\text { Horn } \\
\text { Circumference }\end{array}$} & $\mathrm{Mu}$ & $17.18 \pm 0.16$ & 1.70 & 12.00 & 21.00 & 9.90 & $\mathrm{Mu}$ & NR & $-2.31 * \pm 0.33$ & 0.0001 \\
\hline & NR & $19.49 \pm 0.29$ & 1.76 & 17.00 & 25.00 & 9.02 & $\mathrm{Mu}$ & Goj & $-2.69 * \pm 0.24$ & $\underline{0.0001}$ \\
\hline & Goj & $19.87 \pm 0.18$ & 1.73 & 17.00 & 28.00 & 8.70 & NR & Goj & $-0.38 \pm 0.34$ & $\underline{0.488}$ \\
\hline \multirow{3}{*}{ Hip Bone } & $\mathrm{Mu}$ & $55.55 \pm 0.29$ & 3.13 & 49.00 & 63.00 & 5.61 & $\mathrm{Mu}$ & NR & $15.95 * \pm 0.6$ & 0.0001 \\
\hline & NR & $39.59 \pm 0.36$ & 2.20 & 34.00 & 43.00 & 5.56 & $\mathrm{Mu}$ & Goj & $1.95 * \pm 0.45$ & 0.0001 \\
\hline & Goj & $53.60 \pm 0.37$ & 3.53 & 30.00 & 60.00 & 6.69 & NR & Goj & $-14.00 * \pm 0.62$ & $\underline{0.0001}$ \\
\hline \multirow{3}{*}{ Plin Bone } & $\mathrm{Mu}$ & $16.94 \pm 0.10$ & 1.08 & 15.00 & 20.00 & 6.32 & $\mathrm{Mu}$ & NR & $2.83 * \pm 0.54$ & 0.0001 \\
\hline & NR & $14.11 \pm 0.30$ & 1.81 & 10.00 & 17.00 & 12.80 & $\mathrm{Mu}$ & Goj & $-7.37 * \pm 0.40$ & 0.0001 \\
\hline & Goj & $24.30 \pm 0.45$ & 4.31 & 19.00 & 59.00 & 17.69 & NR & Goj & $-10.20 * \pm 0.55$ & $\underline{0.0001}$ \\
\hline \multirow{3}{*}{ T|ail Length } & $\mathrm{Mu}$ & $104.61 \pm 1.24$ & 13.18 & 76.00 & 130.00 & 12.58 & $\mathrm{Mu}$ & NR & $24.26^{*} \pm 2.59$ & 0.0001 \\
\hline & NR & $80.35 \pm 1.06$ & 6.42 & 69.00 & 102.00 & 7.99 & $\mathrm{Mu}$ & Goj & $13.65 * \pm 1.92$ & 0.0001 \\
\hline & Goj & $90.96 \pm 1.68$ & 16.11 & 22.00 & 116.00 & 17.70 & NR & Goj & $-10.60 * \pm 2.66$ & 0.0001 \\
\hline \multirow{3}{*}{$\begin{array}{l}\text { Tail up to } \\
\text { Switch }\end{array}$} & $\mathrm{Mu}$ & $95.14 \pm 1.04$ & 11.01 & 68.00 & 123.00 & 11.56 & $\mathrm{Mu}$ & NR & $25.87 * \pm 1.84$ & 0.0001 \\
\hline & NR & $69.27 \pm 0.98$ & 5.93 & 60.00 & 85.00 & 8.56 & $\mathrm{Mu}$ & Goj & $-9.14 * \pm 1.37$ & 0.0001 \\
\hline & Goj & $104.28 \pm 0.97$ & 9.27 & 73.00 & 124.00 & 8.87 & NR & Goj & $-35.01 * \pm 1.9$ & 0.0001 \\
\hline
\end{tabular}


Table 2 (on next page)

Characteristics of canonical discriminant functions and test statistics

${ }^{\dagger}$ Degrees of freedom 


\begin{tabular}{|c|c|c|c|c|c|c|c|c|}
\hline $\begin{array}{c}\text { Discriminant } \\
\text { Function }\end{array}$ & $\begin{array}{c}\text { Eigen } \\
\text { values }\end{array}$ & $\begin{array}{c}\text { Variance } \\
\text { percentage } \\
\text { explained }\end{array}$ & $\begin{array}{c}\text { Cumulative } \\
\text { variance }\end{array}$ & $\begin{array}{c}\text { Canonical } \\
\text { correlation }\end{array}$ & $\begin{array}{c}\text { Wilks' } \\
\text { Lambda }\end{array}$ & $\begin{array}{c}\text { Chi- } \\
\text { square }\end{array}$ & t.f. & $\boldsymbol{P}$ \\
\hline $1^{\text {st }}$ function & 14.40 & 66.7 & 66.7 & 0.967 & 0.008 & 1134.64 & 20 & 0.0001 \\
\hline $2^{\text {nd }}$ function & 7.19 & 33.3 & 100 & 0.937 & 0.122 & 493.30 & 9 & 0.0001 \\
\hline
\end{tabular}

1 


\section{Table 3(on next page)}

Breed wise details of estimated Genetic Diversity Indices for each microsatellite markers

NE: not estimable in the global analysis of molecular variance 


\begin{tabular}{|c|c|c|c|c|c|c|c|c|c|c|c|}
\hline \multirow{2}{*}{ Locus } & \multicolumn{3}{|c|}{$\begin{array}{c}\text { Expected } \\
\text { Heterozygosity }\left(H_{\mathrm{e}}\right)\end{array}$} & \multicolumn{3}{|c|}{ Theta $H\left(\theta_{H}\right)$} & \multicolumn{3}{|c|}{ Number of alleles $\left(N_{\mathrm{a}}\right)$} & \multirow{2}{*}{$F_{\mathrm{ST}}$} & \multirow{2}{*}{$\begin{array}{c}p \text {-value of } \\
F_{\mathrm{ST}} \\
\text { estimation }\end{array}$} \\
\hline & $\begin{array}{l}\text { Nilli- } \\
\text { Ravi }\end{array}$ & Murrah & Gojri & $\begin{array}{l}\text { Nilli- } \\
\text { Ravi }\end{array}$ & Murrah & Gojri & $\begin{array}{l}\text { Nilli- } \\
\text { Ravi }\end{array}$ & Murrah & Gojri & & \\
\hline BM1818 & 0.69 & 0.68 & 0.71 & 2.29 & 2.17 & 2.49 & 7 & 9 & 6 & 0.029 & 0.078 \\
\hline CSSM19 & 0.74 & 0 & 0.73 & 2.80 & 0 & 2.75 & 6 & 0 & 6 & $\mathrm{NE}$ & $\mathrm{NE}$ \\
\hline CSSM33 & 0.71 & 0.73 & 0.63 & 2.49 & 2.67 & 1.74 & 8 & 9 & 7 & 0.194 & 0.00001 \\
\hline CSSM45 & 0.65 & 0.80 & 0.73 & 1.87 & 3.98 & 2.72 & 5 & 6 & 6 & 0.204 & 0.00001 \\
\hline CSSM47 & 0.81 & 0.69 & 0.82 & 4.23 & 2.25 & 4.63 & 10 & 10 & 11 & 0.175 & 0.00001 \\
\hline CSSM66 & 0.79 & 0.61 & 0.82 & 3.67 & 1.60 & 4.43 & 7 & 6 & 9 & 0.176 & 0.00001 \\
\hline Hel013 & 0.67 & 0.75 & 0.82 & 2.08 & 3 & 4.49 & 8 & 8 & 9 & 0.139 & 0.00001 \\
\hline ILSTS19 & 0.14 & 0.17 & 0.12 & 0.16 & 0.20 & 0.14 & 2 & 6 & 3 & 0.809 & 0.00001 \\
\hline ILSTS25 & 0.58 & 0.61 & 0.72 & 1.39 & 1.59 & 2.52 & 5 & 6 & 8 & 0.179 & 0.00001 \\
\hline ILSTS26 & 0.67 & 0.61 & 0.76 & 2.05 & 1.57 & 3.26 & 6 & 6 & 5 & 0.084 & 0.00001 \\
\hline ILSTS28 & 0.76 & 0.76 & 0.76 & 3.25 & 3.16 & 3.21 & 8 & 7 & 6 & 0.002 & 0.7165 \\
\hline ILSTS29 & 0.33 & 0.26 & 0.82 & 0.49 & 0.35 & 4.49 & 6 & 4 & 10 & 0.376 & 0.00001 \\
\hline ILSTS30 & 0.71 & 0.60 & 0.69 & 2.45 & 1.47 & 2.25 & 7 & 6 & 6 & 0.194 & 0.00001 \\
\hline ILSTS33 & 0.66 & 0.68 & 0.59 & 1.99 & 2.14 & 1.47 & 6 & 7 & 3 & 0.005 & 0.51026 \\
\hline ILSTS36 & 0.66 & 0.67 & 0.72 & 1.98 & 2.03 & 2.58 & 6 & 6 & 12 & 0.160 & 0.00001 \\
\hline ILSTS52 & 0.67 & 0 & 0.73 & 2.00 & 0 & 2.72 & 9 & 0 & 8 & $\mathrm{NE}$ & $\mathrm{NE}$ \\
\hline ILSTS56 & 0.40 & 0.53 & 0.59 & 0.67 & 1.12 & 1.45 & 5 & 7 & 8 & 0.345 & 0.00001 \\
\hline ILSTS58 & 0.81 & 0.85 & 0.77 & 4.24 & 5.70 & 3.40 & 7 & 9 & 11 & 0.088 & 0.00001 \\
\hline ILSTS60 & 0.45 & 0.36 & 0.60 & 0.81 & 0.57 & 1.53 & 4 & 3 & 14 & 0.016 & 0.18573 \\
\hline ILSTS61 & 0.66 & 0.81 & 0.76 & 1.91 & 4.23 & 3.23 & 6 & 13 & 11 & 0.178 & 0.00001 \\
\hline ILSTS089 & 0 & 0.79 & 0.76 & 0 & 3.76 & 3.14 & 0 & 6 & 6 & $\mathrm{NE}$ & $\mathrm{NE}$ \\
\hline ILSTS95 & 0.80 & 0.71 & 0.71 & 4.08 & 2.43 & 2.48 & 10 & 11 & 8 & 0.061 & 0.00001 \\
\hline Mean & 0.61 & 0.58 & 0.70 & 1.55 & 1.36 & 2.33 & 6.27 & 6.59 & 7.86 & 0.18 & - \\
\hline SD & 0.22 & 0.25 & 0.15 & - & - & - & 2.33 & 3.10 & 2.83 & - & - \\
\hline
\end{tabular}




\section{Table 4 (on next page)}

Results of Global Molecular Analysis of Variance (AMOVA) along with fixation indices in Northern India buffalo populations 


\begin{tabular}{|c|c|c|c|c|c|c|}
\hline $\begin{array}{l}\text { Sources of } \\
\text { Variation }\end{array}$ & $\begin{array}{l}\text { Degrees } \\
\text { of } \\
\text { Freedom }\end{array}$ & $\begin{array}{l}\text { Sum of } \\
\text { Squares }\end{array}$ & $\begin{array}{c}\text { Variance } \\
\text { components }\end{array}$ & $\begin{array}{c}\text { Variation } \\
\text { explained } \\
(\%)\end{array}$ & $\begin{array}{c}\text { Fixation } \\
\text { indices }\end{array}$ & $P$ Value \\
\hline Among populations & 2 & 232.21 & 1.38 & 18.25 & $\begin{array}{l}0.182 \\
\left(F_{\mathrm{ST}}\right)\end{array}$ & 0.00001 \\
\hline $\begin{array}{l}\text { Among individuals } \\
\text { within populations }\end{array}$ & 125 & 786.65 & 0.73 & 9.60 & $\begin{array}{l}0.117 \\
\left(F_{\text {IS }}\right)\end{array}$ & 0.00001 \\
\hline Within individuals & 128 & 640.50 & 5.46 & 72.15 & $\begin{array}{l}0.278 \\
\left(F_{\mathrm{IT}}\right)\end{array}$ & 0.00001 \\
\hline Total & 255 & 1659.37 & 7.57 & 100 & - & - \\
\hline
\end{tabular}

1 


\section{Table 5 (on next page)}

Individual wise ancestry level inferred through Bayesian method in Structure

NR, MU, and Goj represent Nili-Ravi, Murrah, and Gojri, respectively 


\begin{tabular}{|c|c|c|c|c|}
\hline \multirow{2}{*}{ Label } & \multirow{2}{*}{ Population } & \multicolumn{3}{|c|}{ Inferred clusters } \\
\cline { 3 - 5 } & 1 & Goj & NR & MU \\
\hline NR1 & 1 & 0.002 & 0.969 & 0.029 \\
\hline NR2 & 1 & 0.002 & 0.988 & 0.011 \\
\hline NR3 & 1 & 0.008 & 0.958 & 0.034 \\
\hline NR4 & 1 & 0.004 & 0.958 & 0.038 \\
\hline NR5 & 1 & 0.001 & 0.99 & 0.009 \\
\hline NR6 & 1 & 0.002 & 0.994 & 0.004 \\
\hline NR7 & 1 & 0.003 & 0.991 & 0.005 \\
\hline NR8 & 1 & 0.002 & 0.992 & 0.006 \\
\hline NR9 & 1 & 0.004 & 0.975 & 0.021 \\
\hline NR10 & 1 & 0.002 & 0.994 & 0.004 \\
\hline NR11 & 1 & 0.002 & 0.987 & 0.011 \\
\hline NR12 & 1 & 0.002 & 0.992 & 0.006 \\
\hline NR13 & 1 & 0.005 & 0.987 & 0.007 \\
\hline NR14 & 1 & 0.004 & 0.991 & 0.005 \\
\hline NR15 & 1 & 0.001 & 0.928 & 0.071 \\
\hline NR16 & 1 & 0.002 & 0.601 & 0.397 \\
\hline NR17 & 1 & 0.001 & 0.993 & 0.006 \\
\hline NR18 & 1 & 0.004 & 0.959 & 0.037 \\
\hline NR19 & 1 & 0.002 & 0.993 & 0.005 \\
\hline NR20 & 1 & 0.002 & 0.947 & 0.051 \\
\hline NR21 & 1 & 0.003 & 0.984 & 0.013 \\
\hline NR22 & 1 & 0.005 & 0.99 & 0.005 \\
\hline NR23 & 1 & 0.004 & 0.99 & 0.006 \\
\hline NR24 & 1 & 0.002 & 0.993 & 0.005 \\
\hline NR25 & 1 & 0.002 & 0.991 & 0.007 \\
\hline NR26 & 1 & 0.004 & 0.993 & 0.003 \\
\hline NR27 & 1 & 0.020 & 0.973 & 0.008 \\
\hline NR28 & 1 & 0.002 & 0.996 & 0.003 \\
\hline NR29 & 1 & 0.001 & 0.995 & 0.004 \\
\hline NR30 & 1 & 0.003 & 0.981 & 0.015 \\
\hline NR31 & 1 & 0.002 & 0.541 & 0.457 \\
\hline NR32 & 1 & 0.002 & 0.993 & 0.005 \\
\hline NR33 & 1 & 0.002 & 0.958 & 0.04 \\
\hline NR34 & 1 & 0.002 & 0.993 & 0.006 \\
\hline NR35 & 1 & 0.001 & 0.993 & 0.006 \\
\hline NR36 & 1 & 0.003 & 0.994 & 0.004 \\
\hline NR37 & 1 & 0.001 & 0.988 & 0.01 \\
\hline NR38 & 1 & 0.003 & 0.986 & 0.011 \\
\hline NR39 & 1 & 0.04 & 0.843 & 0.118 \\
\hline
\end{tabular}




\begin{tabular}{|c|c|c|c|c|}
\hline NR40 & 1 & 0.003 & 0.994 & 0.003 \\
\hline MU1 & 2 & 0.004 & 0.015 & 0.981 \\
\hline MU2 & 2 & 0.28 & 0.707 & 0.013 \\
\hline MU3 & 2 & 0.003 & 0.003 & 0.993 \\
\hline MU4 & 2 & 0.005 & 0.007 & 0.988 \\
\hline MU5 & 2 & 0.001 & 0.003 & 0.995 \\
\hline MU6 & 2 & 0.005 & 0.013 & 0.983 \\
\hline MU7 & 2 & 0.008 & 0.048 & 0.944 \\
\hline MU8 & 2 & 0.004 & 0.946 & 0.05 \\
\hline MU9 & 2 & 0.002 & 0.003 & 0.995 \\
\hline MU10 & 2 & 0.003 & 0.01 & 0.987 \\
\hline MU11 & 2 & 0.002 & 0.004 & 0.994 \\
\hline MU12 & 2 & 0.002 & 0.119 & 0.879 \\
\hline MU13 & 2 & 0.003 & 0.229 & 0.768 \\
\hline MU14 & 2 & 0.003 & 0.461 & 0.536 \\
\hline MU15 & 2 & 0.005 & 0.004 & 0.99 \\
\hline MU16 & 2 & 0.005 & 0.019 & 0.976 \\
\hline MU17 & 2 & 0.01 & 0.303 & 0.687 \\
\hline MU18 & 2 & 0.002 & 0.018 & 0.979 \\
\hline MU19 & 2 & 0.039 & 0.36 & 0.602 \\
\hline MU20 & 2 & 0.002 & 0.006 & 0.992 \\
\hline MU21 & 2 & 0.003 & 0.003 & 0.995 \\
\hline MU22 & 2 & 0.004 & 0.804 & 0.192 \\
\hline MU23 & 2 & 0.007 & 0.164 & 0.829 \\
\hline MU24 & 2 & 0.003 & 0.007 & 0.99 \\
\hline MU25 & 2 & 0.003 & 0.004 & 0.993 \\
\hline MU26 & 2 & 0.002 & 0.065 & 0.933 \\
\hline MU27 & 2 & 0.001 & 0.011 & 0.988 \\
\hline MU28 & 2 & 0.017 & 0.084 & 0.899 \\
\hline MU29 & 2 & 0.022 & 0.049 & 0.929 \\
\hline MU30 & 2 & 0.002 & 0.011 & 0.987 \\
\hline MU31 & 2 & 0.002 & 0.007 & 0.991 \\
\hline MU32 & 2 & 0.014 & 0.438 & 0.548 \\
\hline MU33 & 2 & 0.002 & 0.004 & 0.995 \\
\hline MU34 & 2 & 0.002 & 0.009 & 0.99 \\
\hline MU35 & 2 & 0.004 & 0.02 & 0.975 \\
\hline MU36 & 2 & 0.004 & 0.983 & 0.013 \\
\hline MU37 & 2 & 0.002 & 0.004 & 0.994 \\
\hline MU38 & 2 & 0.005 & 0.015 & 0.98 \\
\hline MU39 & 2 & 0.005 & 0.104 & 0.891 \\
\hline MU40 & 2 & 0.002 & 0.01 & 0.988 \\
\hline
\end{tabular}




\begin{tabular}{|c|c|c|c|c|}
\hline Goj1 & 3 & 0.995 & 0.002 & 0.003 \\
\hline Goj2 & 3 & 0.995 & 0.002 & 0.003 \\
\hline Goj3 & 3 & 0.996 & 0.002 & 0.001 \\
\hline Goj4 & 3 & 0.991 & 0.006 & 0.003 \\
\hline Goj5 & 3 & 0.996 & 0.002 & 0.002 \\
\hline Goj6 & 3 & 0.993 & 0.004 & 0.002 \\
\hline Goj7 & 3 & 0.997 & 0.001 & 0.002 \\
\hline Goj8 & 3 & 0.988 & 0.008 & 0.004 \\
\hline Goj9 & 3 & 0.995 & 0.002 & 0.003 \\
\hline Goj10 & 3 & 0.989 & 0.006 & 0.005 \\
\hline Goj11 & 3 & 0.997 & 0.001 & 0.002 \\
\hline Goj12 & 3 & 0.997 & 0.001 & 0.002 \\
\hline Goj13 & 3 & 0.997 & 0.001 & 0.002 \\
\hline Goj14 & 3 & 0.997 & 0.001 & 0.002 \\
\hline Goj15 & 3 & 0.991 & 0.003 & 0.006 \\
\hline Goj16 & 3 & 0.995 & 0.002 & 0.002 \\
\hline Goj17 & 3 & 0.996 & 0.002 & 0.002 \\
\hline Goj18 & 3 & 0.995 & 0.003 & 0.002 \\
\hline Goj19 & 3 & 0.991 & 0.005 & 0.004 \\
\hline Goj20 & 3 & 0.986 & 0.009 & 0.005 \\
\hline Goj21 & 3 & 0.997 & 0.001 & 0.002 \\
\hline Goj22 & 3 & 0.996 & 0.002 & 0.002 \\
\hline Goj23 & 3 & 0.99 & 0.004 & 0.006 \\
\hline Goj24 & 3 & 0.997 & 0.001 & 0.001 \\
\hline Goj25 & 3 & 0.996 & 0.002 & 0.002 \\
\hline Goj26 & 3 & 0.996 & 0.002 & 0.002 \\
\hline Goj27 & 3 & 0.997 & 0.002 & 0.002 \\
\hline Goj28 & 3 & 0.995 & 0.002 & 0.002 \\
\hline Goj29 & 3 & 0.995 & 0.002 & 0.003 \\
\hline Goj30 & 3 & 0.995 & 0.002 & 0.002 \\
\hline Goj31 & 3 & 0.995 & 0.002 & 0.003 \\
\hline Goj32 & 3 & 0.994 & 0.003 & 0.004 \\
\hline Goj33 & 3 & 0.992 & 0.004 & 0.004 \\
\hline Goj34 & 3 & 0.996 & 0.002 & 0.002 \\
\hline Goj35 & 3 & 0.995 & 0.002 & 0.003 \\
\hline Goj36 & 3 & 0.995 & 0.002 & 0.003 \\
\hline Goj37 & 3 & 0.992 & 0.004 & 0.005 \\
\hline Goj38 & 3 & 0.995 & 0.002 & 0.003 \\
\hline Goj39 & 3 & 0.992 & 0.001 & 0.006 \\
\hline Goj40 & 3 & 0.996 & 0.002 & 0.002 \\
\hline Goj41 & 3 & 0.994 & 0.003 & 0.004 \\
\hline & & & & \\
\hline
\end{tabular}




\begin{tabular}{|l|l|l|l|l|}
\hline Goj42 & 3 & 0.967 & 0.006 & 0.026 \\
\hline Goj43 & 3 & 0.989 & 0.003 & 0.008 \\
\hline Goj44 & 3 & 0.994 & 0.003 & 0.003 \\
\hline Goj45 & 3 & 0.988 & 0.006 & 0.006 \\
\hline Goj46 & 3 & 0.997 & 0.001 & 0.002 \\
\hline Goj47 & 3 & 0.993 & 0.003 & 0.004 \\
\hline Goj48 & 3 & 0.991 & 0.002 & 0.007 \\
\hline
\end{tabular}

1 
Figure 1

Canonical Discriminant Analysis (Scatter Plot) based on 13 body morphometric traits depicted three different buffalo populations from Northern India

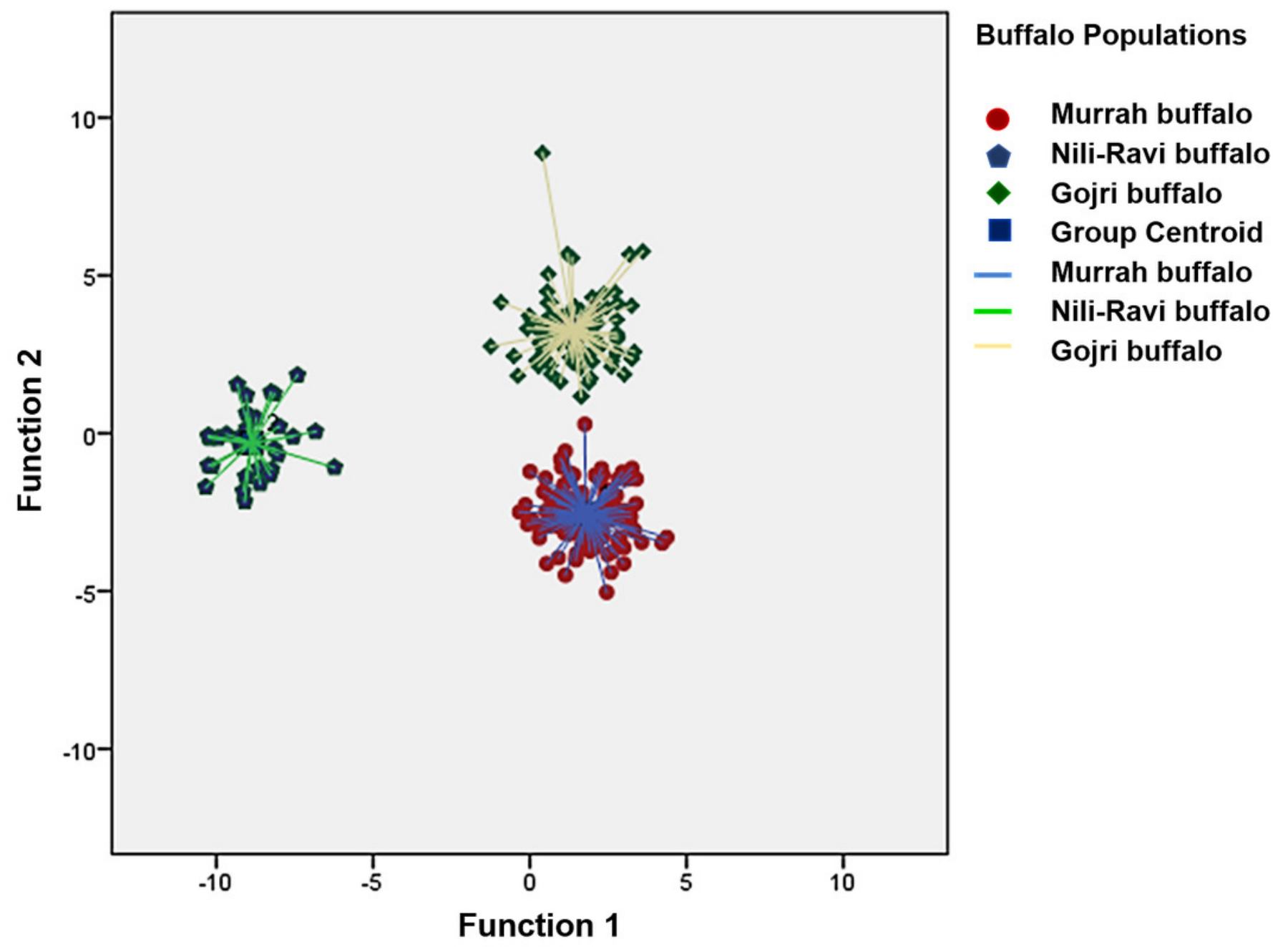




\section{Figure 2}

Heatmap of molecular diversity indices

(a) pairwise $F_{\mathrm{ST}}$ (b) Slatkin's linearized $F_{\mathrm{ST}}$ (c) Nei's distance and AMOVA

(a)

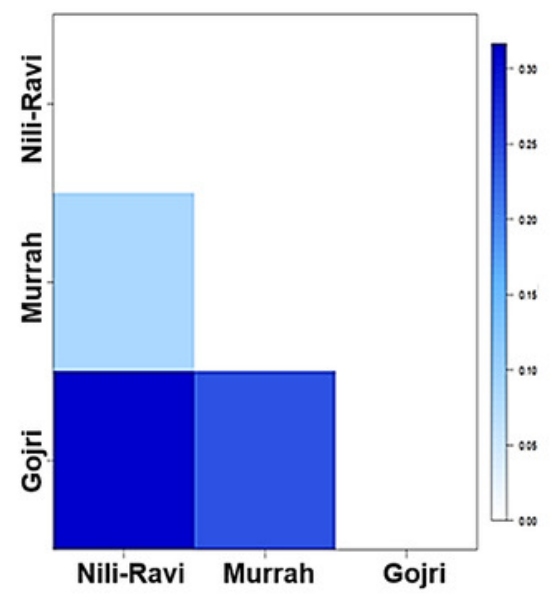

(b)

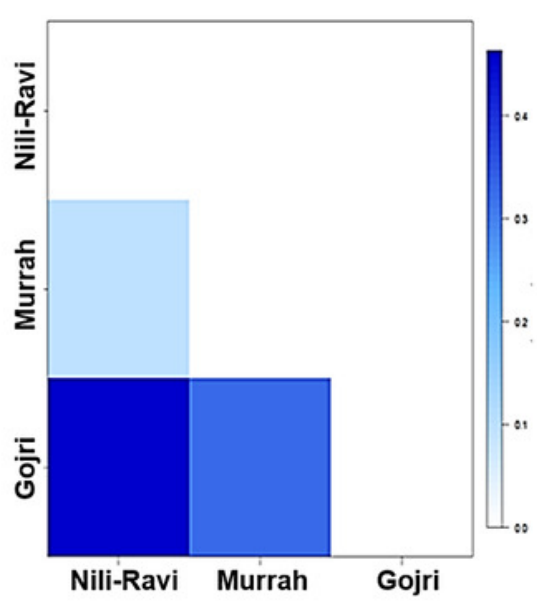

(c)

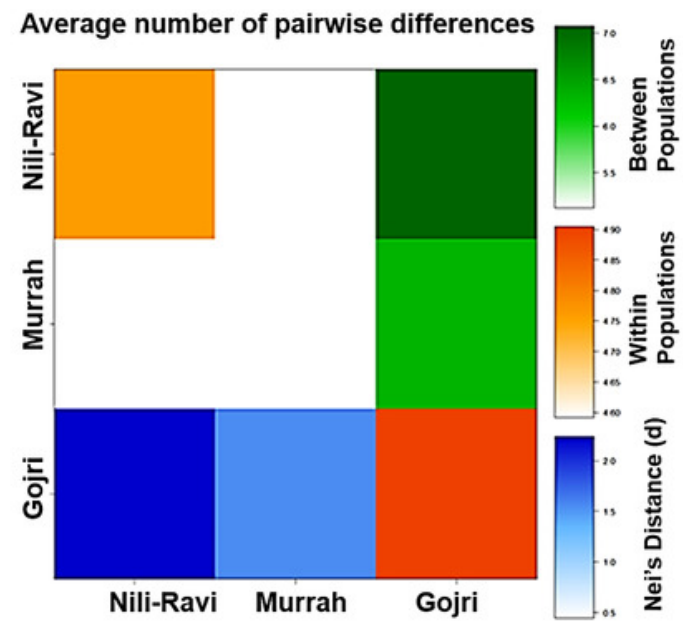


Figure 3

Scatter plot for Factorial Correspondence Analysis based on genetic diversity indices depicted three different buffalo populations from Northern India

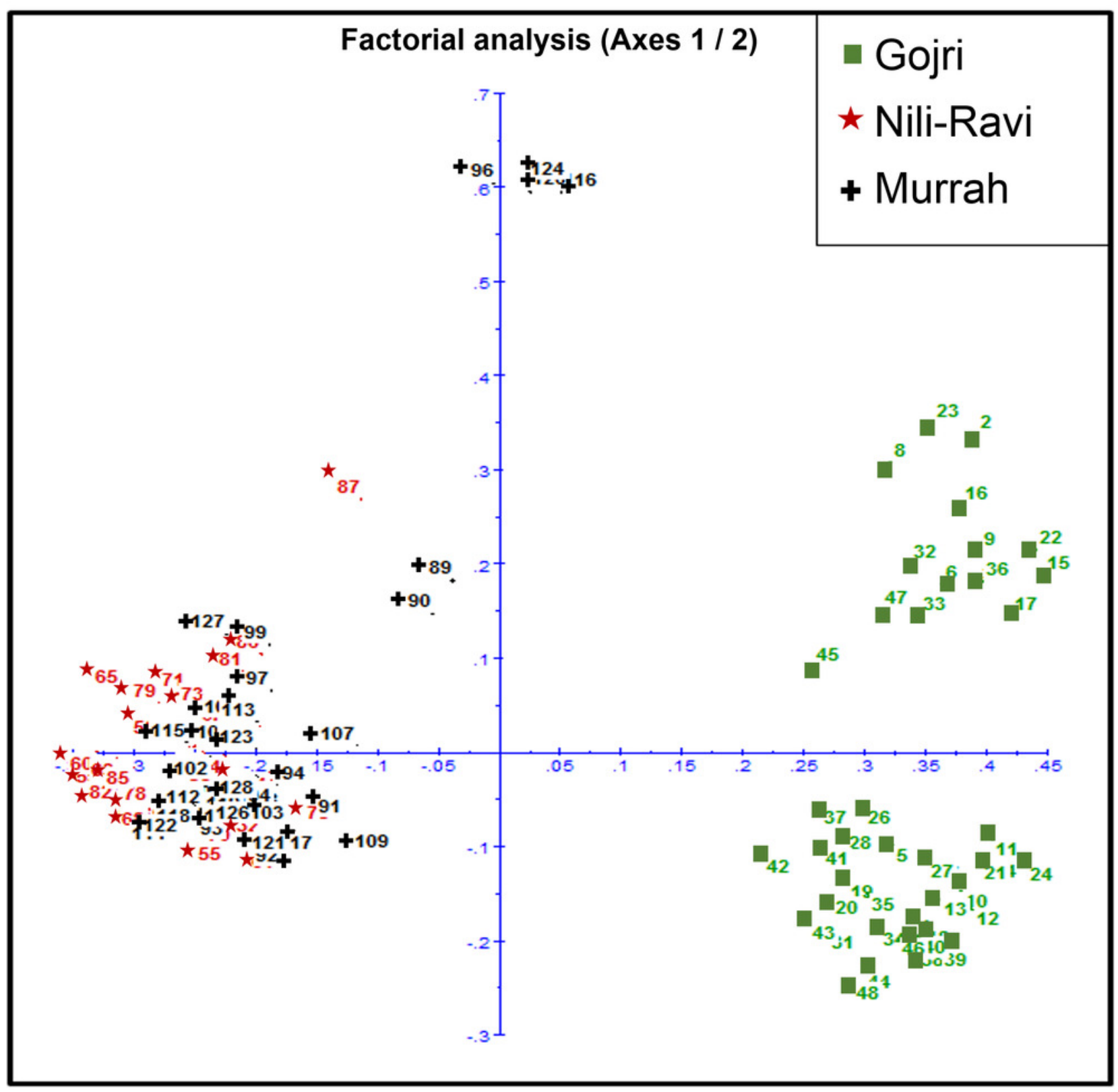


Figure 4

Estimates of number of sub-populations $(K)$ using different statistics by Evanno method to determine ideal number of clusters present in the studied buffalo populations

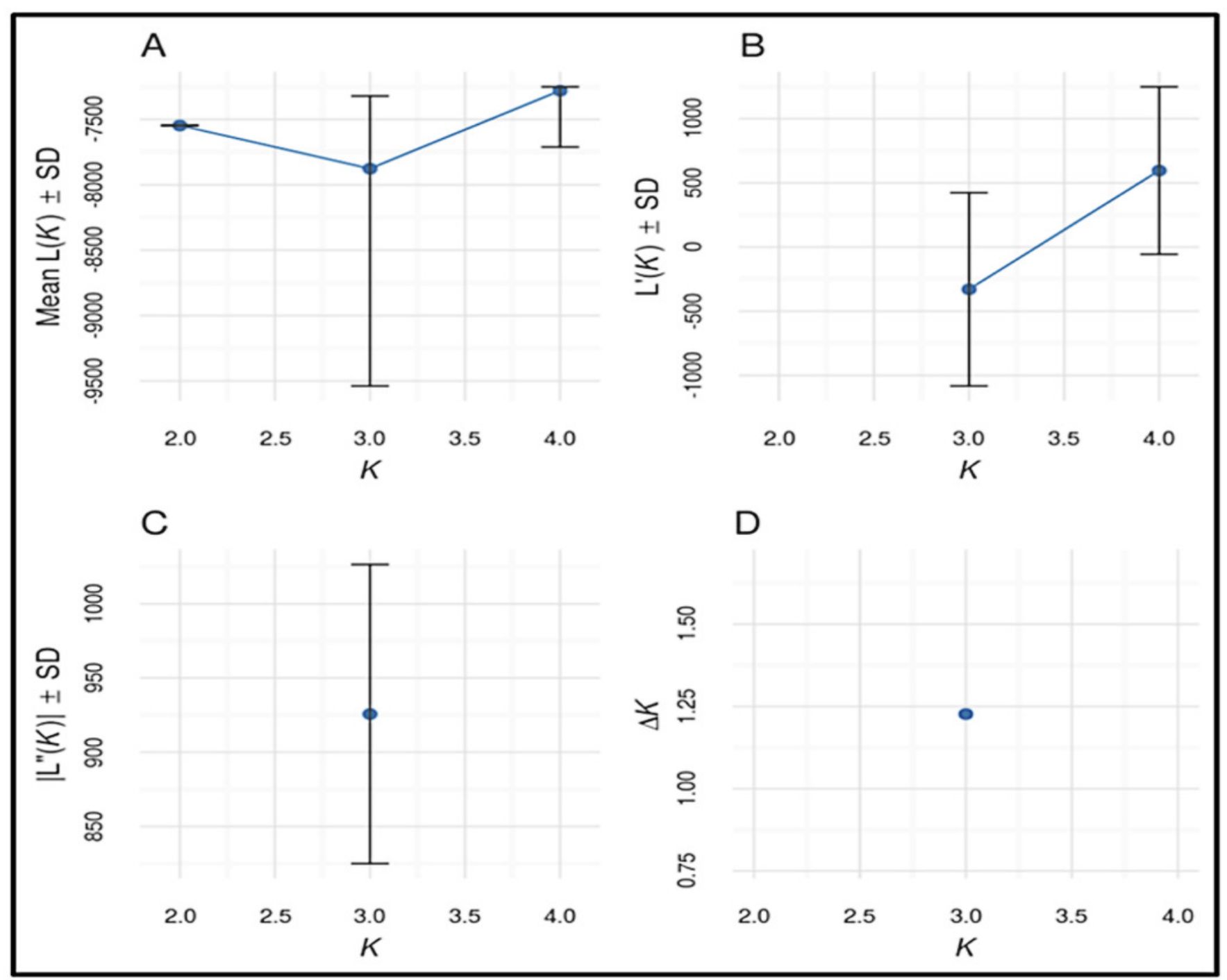




\section{Figure 5}

Bayesian clustering of North-Indian buffalo populations under the assumption of $\mathrm{K}=2-4$ using STRUCTURE program reveals genetic admixture and introgression among Murrah and Nili-Ravi populations while Gojri buffalo is genetically distinct.

Each vertical bar represents individuals displaying membership coefficients for each population cluster. Populations are separated by dashed white lines. Graphics were obtained with CLUMPP (Jakobsson \& Rosenberg, 2007).

$$
K=2
$$

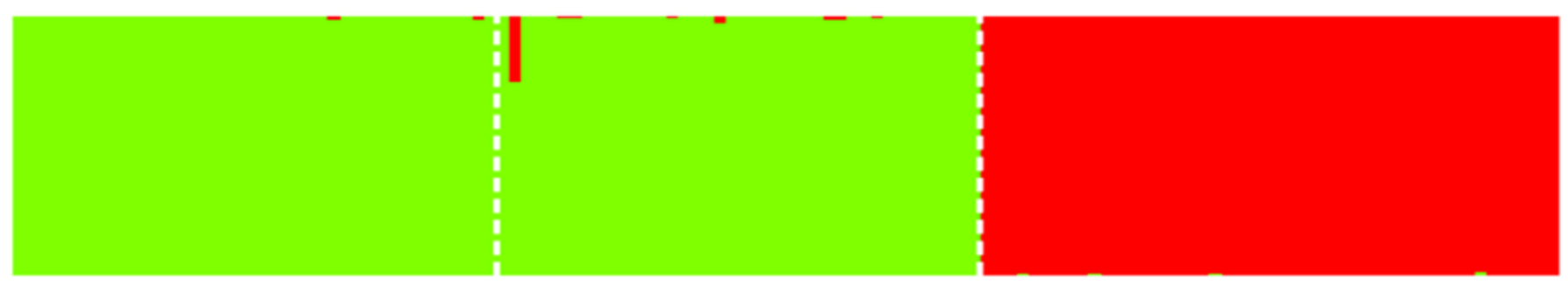

$$
K=3
$$
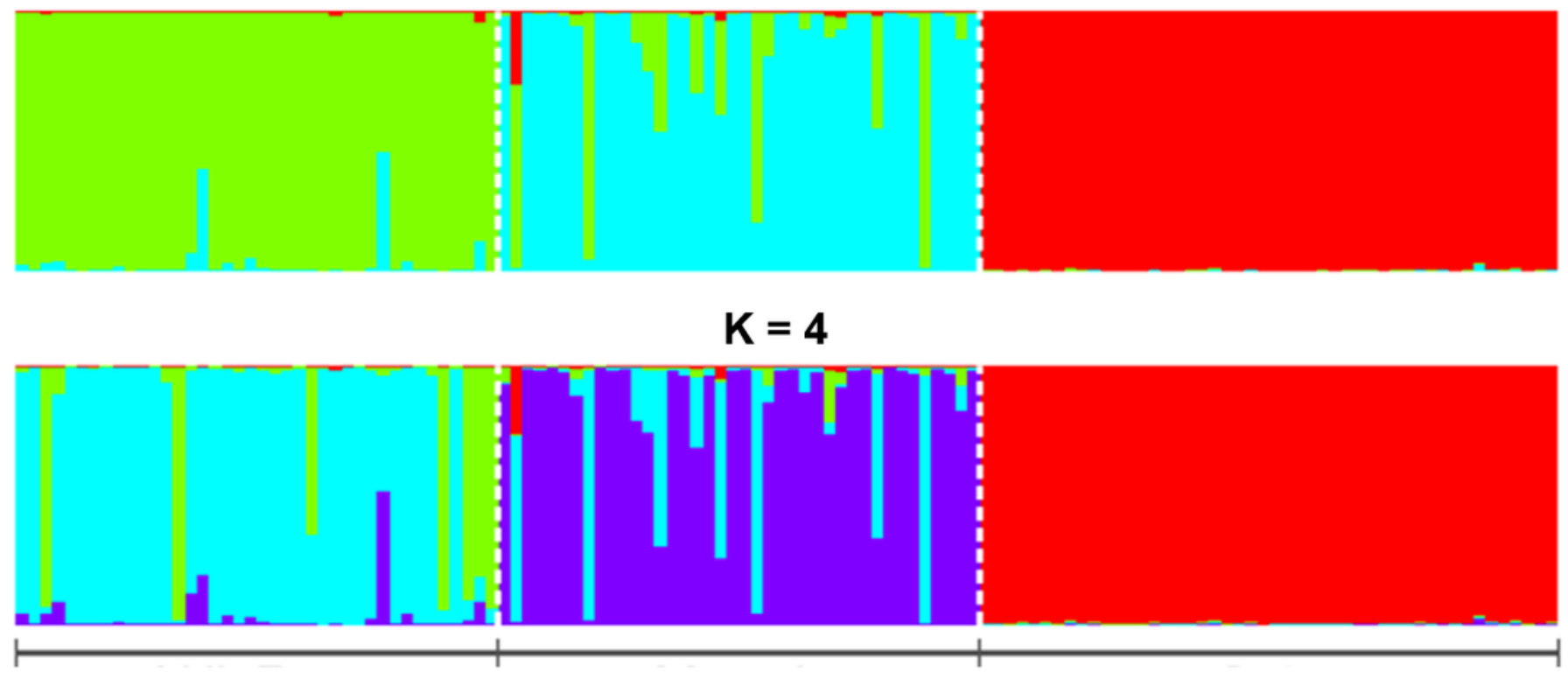

Nili-Ravi

Murrah

Gojri 